\title{
Sewage input effects on the macroinvertebrate community associated to Typha domingensis Pers in a coastal lagoon in southeastern Brazil
}

\author{
Henriques-de-Oliveira, C. ${ }^{\mathrm{a} *}$, Baptista, DF. ${ }^{\mathrm{b}}$ and Nessimian, $J \mathrm{~L}^{\mathrm{a}}$ \\ aLaboratório de Entomologia, Departamento de Zoologia, Instituto de Biologia, Universidade Federal do Rio de Janeiro, \\ CP 68044, CEP 21944-970, Cidade Universitária, Rio de Janeiro, RJ, Brazil \\ 'baboratório de Avaliação e Promoção da Saúde Ambiental, Departamento de Biologia, Instituto Owaldo Cruz - FIOCRUZ \\ *e-mail: crikes@acd.ufrj.br \\ Received March 16, 2005 - Accepted May 30, 2005 - Distributed February 28, 2007
}

(With 3 figures)

\begin{abstract}
This study was carried out at Imboassica Lagoon, located in an urban zone in the municipality of Macaé, Rio de Janeiro state, Brazil. This lagoon has been subject to anthropogenic impacts due to the increasing city population, such as the input of sewage. Areas of variable degree of anthropogenic influence in the lagoon were compared regarding the structure of the macroinvertebrate community associated to Typha domingensis leaves. For sampling, we used $35 \times 20 \mathrm{~cm}$ net plastic bags, with $6.8 \mathrm{~mm}$ mesh containing T. domingensis leaves for colonization. Two different sampling stations were selected: station A, under direct input of sewage; and station B with lesser sewage influence. The bags were removed after 20, 40 and 75 days of colonization. For each sample the Shannon-Wiever Diversity, Pielou Evenness, Jaccard Similarity Indices, Correspondence Analysis and taxonomic richness were calculated. A total of 31,874 individuals were sampled, belonging to 34 taxa. The main taxonomical groups were: Oligochaeta (41\%), Chironomidae (40\%), Ancylidae (4.6\%), Polymitarcyidae (4\%) and Thiaridae (3\%). At station A, the taxonomic richness, the Evenness and Diversity values were lower than in station B. On the other hand, the total density was three times higher in station A than in B. It was already possible to discriminate the community structure of each sampling station in the first sampling. Trichoptera and Ephemeroptera were the main exclusive groups of station B and are considered good water quality indicators due to their high sensibility to contamination. The major contribution to discriminate between the macroinvertebrate communities of the two sample stations came from Chironomidae, Oligochaeta and Ephemeroptera.
\end{abstract}

Keywords: macroinvertebrates, coastal lagoons, macrophytes colonization, Typha domingensis, eutrophication.

\section{Efeitos do aporte de esgotos sobre a comunidade de macroinvertebrados associada à Typha domingensis Pers em uma lagoa costeira no Sudeste do Brasil}

\begin{abstract}
Resumo
O presente estudo foi realizado na Lagoa Imboassica, localizada no perímetro urbano da cidade de Macaé, RJ, Brasil. Esta lagoa vem sofrendo impactos antrópicos com o aumento da cidade, como o aporte de esgotos sem tratamento. Áreas com diferentes graus de influência antrópica na lagoa foram comparadas quanto à estrutura da fauna de macroinvertebrados associada a folhas de Typha domingensis. A amostragem da fauna foi realizada por meio de cestos de tela plástica de $35 \times 20 \mathrm{~cm}$ e malha de $6,8 \mathrm{~mm}$, com folhas de T. domingensis para colonização. Dois pontos amostrais foram selecionados: ponto A, sujeito a aporte direto de esgotos; e ponto B, sob menor influência de esgotos. Os cestos foram retirados após 20, 40 e 75 dias de colonização. Foram aplicados em cada amostra os índices de diversidade de Shannon-Wiever, equitabilidade de Pielou e similaridade de Jaccard, riqueza taxonômica e Análise de Correspondência. Foram encontrados 31.874 indivíduos, distribuídos em 34 táxons. Os principais grupos foram: Oligochaeta (41\%); Chironomidae (40\%); Ancylidae (4,6\%); Polimitarcyidae (4\%); e Thyaridae (3\%). No ponto A, os valores de riqueza taxonômica, equitabilidade e diversidade foram inferiores aos do ponto B. Por outro lado, a densidade total foi três vezes maior no ponto A. A estrutura da comunidade foi diferente nos dois pontos amostrais para todos os testes utilizados, desde a primeira retirada. Trichoptera e Ephemeroptera foram os principais grupos exclusivos do ponto $\mathrm{B}$, sendo considerados indicadores da qualidade da água devido à sua sensibilidade. Chironomidae, Oligochaeta e Ephemeroptera foram os principais grupos a contribuir com as diferenças nas comunidades de macroinvertebrados entre os pontos amostrais.
\end{abstract}

Palavras-chave: macroinvertebrados, lagoas costeiras, colonização de macrófitas, Typha domingensis, eutrofização. 


\section{Introduction}

Coastal lagoons are abundant on the Brazilian coast, especially in Rio de Janeiro and Rio Grande do Sul States (Esteves, 1998a). Such lagoons show primary productivity comparable to estuarine environments and have many important resources for human exploitation (e.g., fishing, production of macrophytes for feeding, fertilizers, handcrafts and tourism) (Esteves et al., 1984). Contrasting to temperate lakes, in tropical coastal lagoons the primary productivity of macrophytes and associated periphyton is relatively more important than the phytoplankton productivity. Aquatic and semi-aquatic macrophytes usually contain larger macroinvertebrate densities than other substrates (Minshall, 1984). Macrophytes are substratum for the main food sources exploited by macroinvertebrates: periphyton and particulate organic matter (Ward, 1992). Moreover, the macrophytes produce debris and increase the habitat heterogeneity leading to higher diversity of the macroinvertebrate fauna (Hynes, 1970; Minshall, 1984).

The coastal lagoons of northern Rio de Janeiro State, Brazil have undergone various anthropogenic impacts since the first half of the XX century (Soffiati, 1998). The sewage input may act as an energy source or a stress factor for an ecosystem, altering its productivity and community development. An effect associated to the stress hypothesis is the decrease of species diversity, as a result of the taxonomic richness decrease and the dominance increase of a few more resistant species (Odum, 1985, 1988). Freshwater macroinvertebrates have been frequently used in water quality studies. The main advantages regarding their use in these studies are the great number of species that may be sensitive to environmental stress, their wide distribution in various freshwater habitats and the relatively sedentary behavior and short life cycle in relation to fish, which facilitates the detection of temporal changes (Rosenberg and Resh, 1993).

In this study, a natural substrate, leaves from Typha domingensis Pers (Thyphaceae), was used for benthic macroinvertebrates colonization. T. domingensis is the dominant macrophyte surrounding the Imboassica Lagoon and represents the main vegetable substrate to periphyton and invertebrates. The sewage input causes eutrophication and increases suspension detritus that deposit on the macrophyte leaves. The Imboassica lagoon is a mosaic differing in the intensity of domestic sewage input that resumes differences on the limnological and biotic parameters (e.g., suspended detritus, ammonia concentration, fecal coliforms concentrations) (Henriques de Oliveira, 2002; Petrucio and Furtado, 1998). Responses of organisms according to their habits and characteristics deal with differences in community parameters such as dominance, richness, diversity and evenness (Resh and Rosenberg, 1984). The aim of this study is to assess if the variation in raw domestic sewage input influences the macroinvertebrate community structure associated to T. domingensis leaves.

\section{Material and Methods}

\subsection{Study area}

The Imboassica lagoon $\left(22^{\circ} 20^{\prime}\right.$ and $22^{\circ} 25^{\prime} \mathrm{S}$; $41^{\circ} 45^{\prime}$ and $41^{\circ} 55^{\prime} \mathrm{W}$ ) is located in the urban zone of the municipality of Macaé, Rio de Janeiro state, Brazil. It presents a total area of $3.26 \mathrm{~km}^{2}$, maximum width of $1.3 \mathrm{~km}$, length of $5.3 \mathrm{~km}$, average depth of $1.09 \mathrm{~m}$ and average volume of $3.53 \mathrm{~km}^{3}$ (Panosso et al., 1998). Due to the rapid growth of Macaé since the 1960's, the Imboassica Lagoon has been subjected to discharge of raw domestic sewage in different points and about $20 \%$ of its area was landfilled for real estate use (Esteves, 1998b). As a result of these anthropogenic factors, there is a continuous reduction in the lagoon depth leading to an increase in its water surface in relation to volume (Esteves et al., 1984). The reduction in the area/volume rate helps to establish macrophytes. Typha domingensis, the Cyperaceae Eleocharis cf. fistulosa (Mart.) Solms and various species of Poaceae occupy roughly $38 \%$ of the total area of the lagoon (Furtado, 1994).

Two sampling stations subjected to different intensity of raw domestic sewage input were chosen, both in the coastal zone, close to the macrophytes stand (Figure 1). Station A, located close to the main sewage inflow, presented fecal coliform concentrations higher than 2,500 Most Probable Number (MPN)/100 mL, an average oxygen concentration of $8.1 \mathrm{mg} . \mathrm{L}^{-1}$, an ammonia concentra-

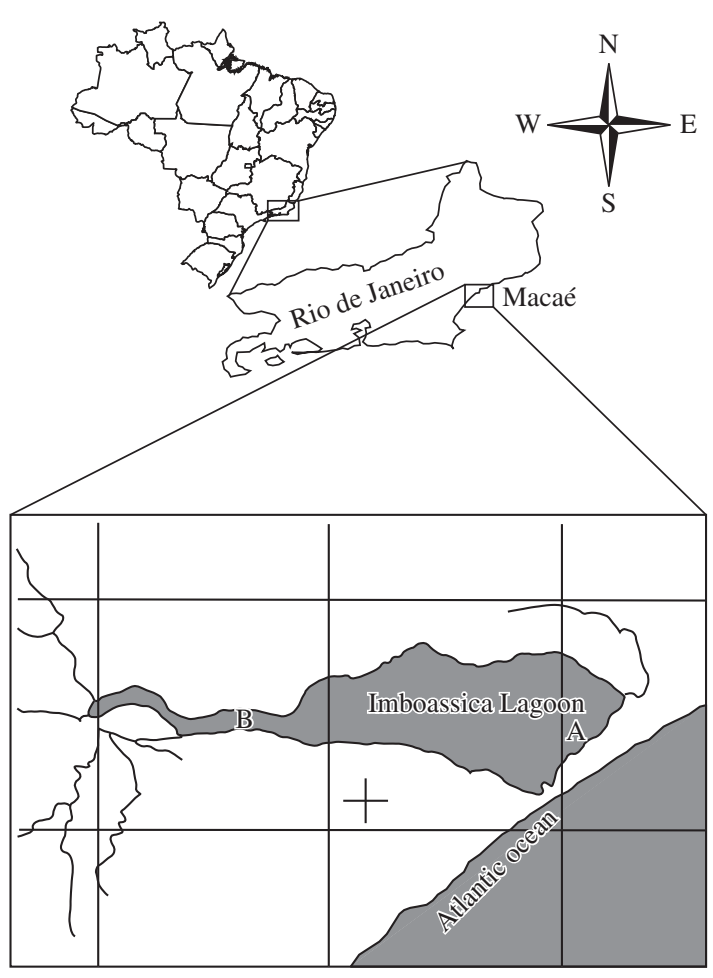

Figure 1. Imboassica Lagoon map, Macaé, RJ. A and B sample stations. 
tion between 11.90 and $26.19 \mathrm{mg} . \mathrm{L}^{-1}$, a pH slightly acid (6.8) and a salinity around 1 S. Station B, representing the control station, is located near the Imboassica River at about $3.5 \mathrm{~km}$ from the station A (Figure 1). It presented fecal coliform concentrations around $500 \mathrm{MPN} / 100 \mathrm{~mL}$, an average oxygen concentration of $5.0 \mathrm{mg} . \mathrm{L}^{-1}$, an ammonia concentration between 0.31 and $2.38 \mathrm{mg} . \mathrm{L}^{-1}$, a pH between 6.7 and 7.3 and salinity values not surpassing $0.9 \mathrm{~S}$.

\subsection{Sampling design}

The benthic macroinvertebrate samples were obtained from colonizing green leaves of Southern Cat-tail, T. domingensis. Emerged parts of the T. domingensis leaves were cut and placed in net plastic bags, with a size of $35 \times 20 \mathrm{~cm}$ and mesh $6.8 \mathrm{~mm}$. Each bag contained $100 \mathrm{~g}$ of leaves. In each station, nine bags were installed, distributed in three sampling sets, with a total of 18 bags in the two stations. The sampling sets were removed after three different colonization periods (20, 40 and 75 days) between November 2000 and January 2001. These time intervals are based on other macroinvertebrate colonization studies and are related to minimum times necessary for establishment and stabilization of the community (Nessimian and De Lima, 1997; Walker, 1998; Gonçalves-Jr., 1999; Kuhlmann, 2000). The leaves were washed and the material retained in sieves of $187 \mu \mathrm{m}$ mesh was sorted and identified under a stereomicroscope with 160x magnification. All specimens were deposited in the Coleção do Departamento de Zoologia da Universidade Federal do Rio de Janeiro.

\subsection{Data analysis}

The shannon index $\left(\mathrm{H}^{\prime}\right)$, Evenness $(\mathrm{J})$ (Magurran, 1988) and richness (number of taxa) were measured for each sample (up to the smaller possible taxonomic level). Hutcheson's method, described by Magurran (1988), calculates the $t$-value and degrees of freedom, testing the significance of differences in diversity between the sampling stations and colonization periods.

The Jaccard Similarity Index was used to evaluate the qualitative macroinvertebrate community similarity among samples. Correspondence Analysis (Ludwig and Reynolds, 1988) was performed on a data matrix of macroinvertebrate densities, with the help of the NTSYS program, version 1.70 (Rohlf, 1992).

\section{Results}

A total of 31,874 macroinvertebrate specimens were collected, distributed through 34 taxa, including 14,779 Insecta and 12,946 Oligochaeta. Regarding the sampling station, 24,739 were found in station A and 7,135 in station B (Table 1). Station A presented smaller taxonomic richness and diversity (Table 2). Oligochaeta was the most representative taxon in this station (49\%), followed by Chironomidae (44\%). Dominant genera of Chironomidae were Goeldichironomus and Chironomus. Ancylidae and Thiaridae (both Gastropoda) completed the group of taxa which presented a relative abundance higher than $1 \%$. In station B 31 taxa were found, amongst which the most abundant were Chironomidae (33\%), Polymitarcyidae (Ephemeroptera) (19\%), Ancylidae (11\%) and Oligochaeta (9\%). Polypedilum (Asheum) was the main Chironomidae taxon. Station B presented higher evenness values than station A (Table 2). Trichoptera and Ephemeroptera were found only in station B, representing roughly $23 \%$ of the total sampled specimens in that station. Other macroinvertebrates found only in station B were Quadrivisio lutzi (Shoemaker, 1933) (Gammaridae; Amphipoda), Micrathyria and Miathyria (both Odonata; Libellulidae), Ceratopogonidae (Diptera) and Helisoma duryi (Wetherby, 1879), Physa marmorata (Guilding, 1828), Pomacea and Melanoides tuberculata (Müller, 1774) (all Gastropoda). Considered together, the latter cited taxa represented roughly $3 \%$ of the total specimens sampled from station B (Table 1). The Jaccard Index distinguished two clusters separating samples of stations A and B (Figure 2).

In the Correspondence Analysis, the first two axes explained together $80 \%$ of the total variation. Axis I (60\% of the variation) might be interpreted as the varia-

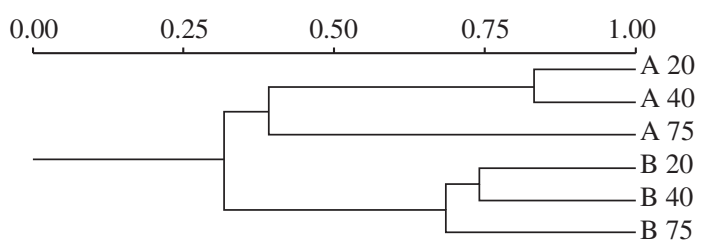

Figure 2. Cluster analysis (UPGMA) from values of Jaccard similarity index of the benthic macroinvertebrates colonizing Typha domingensis leaves during different colonization periods in stations of the Imboassica Lagoon, Macaé, RJ, November, 2000 through January, 2001. Sample stations: A and B; colonization periods: 20, 40 and 75 days.

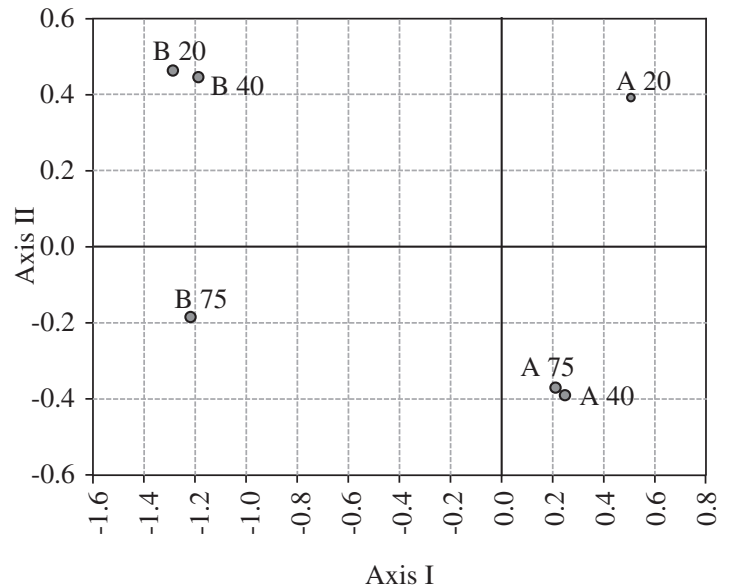

Figure 3. First two components from Correspondence Analysis among colonization periods of Typha domingensis leaves by benthic macroinvertebrates in sample stations of the Imboassica Lagoon, Macaé, RJ, November, 2000 through January, 2001. Sample stations: A and B; colonization periods: 20, 40, and 75 days. 
Table 1. Total abundance of benthic macroinvertebrates colonizing Typha domingensis leaves during different colonization periods in stations A and B of the Imboassica Lagoon, Macaé, RJ, November 2000 through January 2001.

\section{Colonization period (days)}

\begin{tabular}{|c|c|c|c|c|c|c|}
\hline & \multicolumn{3}{|c|}{ Station A } & \multicolumn{3}{|c|}{ Station B } \\
\hline & 20 & 40 & 75 & 20 & 40 & 75 \\
\hline \multicolumn{7}{|l|}{ ARTHROPODA } \\
\hline \multicolumn{7}{|l|}{ INSECTA } \\
\hline COLLEMBOLA & & & 4 & & 3 & \\
\hline \multicolumn{7}{|l|}{ EPHEMEROPTERA } \\
\hline \multicolumn{7}{|l|}{ Baetidae } \\
\hline Callibaetis spp. & & & & 15 & 1 & \\
\hline \multicolumn{7}{|l|}{ Caenidae } \\
\hline Caenis spp. & & & & 8 & 13 & 25 \\
\hline \multicolumn{7}{|l|}{ Polymitarcyidae } \\
\hline Campsurus melanocephalus & & & & 350 & 186 & 839 \\
\hline \multicolumn{7}{|l|}{ ODONATA } \\
\hline Coenagrionidae & 2 & 4 & & 81 & 23 & 43 \\
\hline \multicolumn{7}{|l|}{ Libellulidae } \\
\hline Micrathyria spp. & & & & 8 & 2 & 4 \\
\hline Miathyria sp. & & & & 1 & & 0 \\
\hline Perithemis sp. & 0 & 0 & 3 & 4 & & 1 \\
\hline Brachymesia sp. & 1 & 1 & & 1 & & 5 \\
\hline \multicolumn{7}{|l|}{ HETEROPTERA } \\
\hline Pleidae & & 1 & & & & \\
\hline \multicolumn{7}{|l|}{ TRICHOPTERA } \\
\hline \multicolumn{7}{|l|}{ Polycentropodidae } \\
\hline Cyrnellus sp. & & & & 133 & 39 & 29 \\
\hline \multicolumn{7}{|l|}{ Leptoceridae } \\
\hline Oecetis spp. & & & & 11 & 5 & 11 \\
\hline \multicolumn{7}{|l|}{ Hydroptilidae } \\
\hline Neotrichia sp. & & & & & & 1 \\
\hline \multicolumn{7}{|l|}{ COLEOPTERA } \\
\hline \multicolumn{7}{|l|}{ Hydrophilidae } \\
\hline Berosus sp. & & & 1 & & 1 & \\
\hline \multicolumn{7}{|l|}{ Elateridae } \\
\hline Pachyderini sp. & & & 1 & & & \\
\hline \multicolumn{7}{|l|}{ DIPTERA } \\
\hline Chironomidae & 2405 & 6683 & 1455 & 667 & 254 & 1447 \\
\hline Ceratopogonidae & & & & 3 & & 2 \\
\hline \multicolumn{7}{|l|}{ CRUSTACEA } \\
\hline CLADOCERA & 1 & 5 & & 65 & 21 & 208 \\
\hline COPEPODA & 12 & 1 & 11 & 162 & 15 & 69 \\
\hline \multicolumn{7}{|l|}{ ISOPODA } \\
\hline \multicolumn{7}{|l|}{ Sphaeromatidae } \\
\hline Exosphaeroma sp. & 5 & 5 & & 23 & 24 & 44 \\
\hline OSTRACODA & 5 & 31 & 27 & 93 & 47 & 95 \\
\hline ARACHNIDA & & & & & & \\
\hline ACARINA & & & 1 & 3 & 1 & 10 \\
\hline ARANEAE & & & & & 2 & 5 \\
\hline
\end{tabular}


Table 1. Continued...

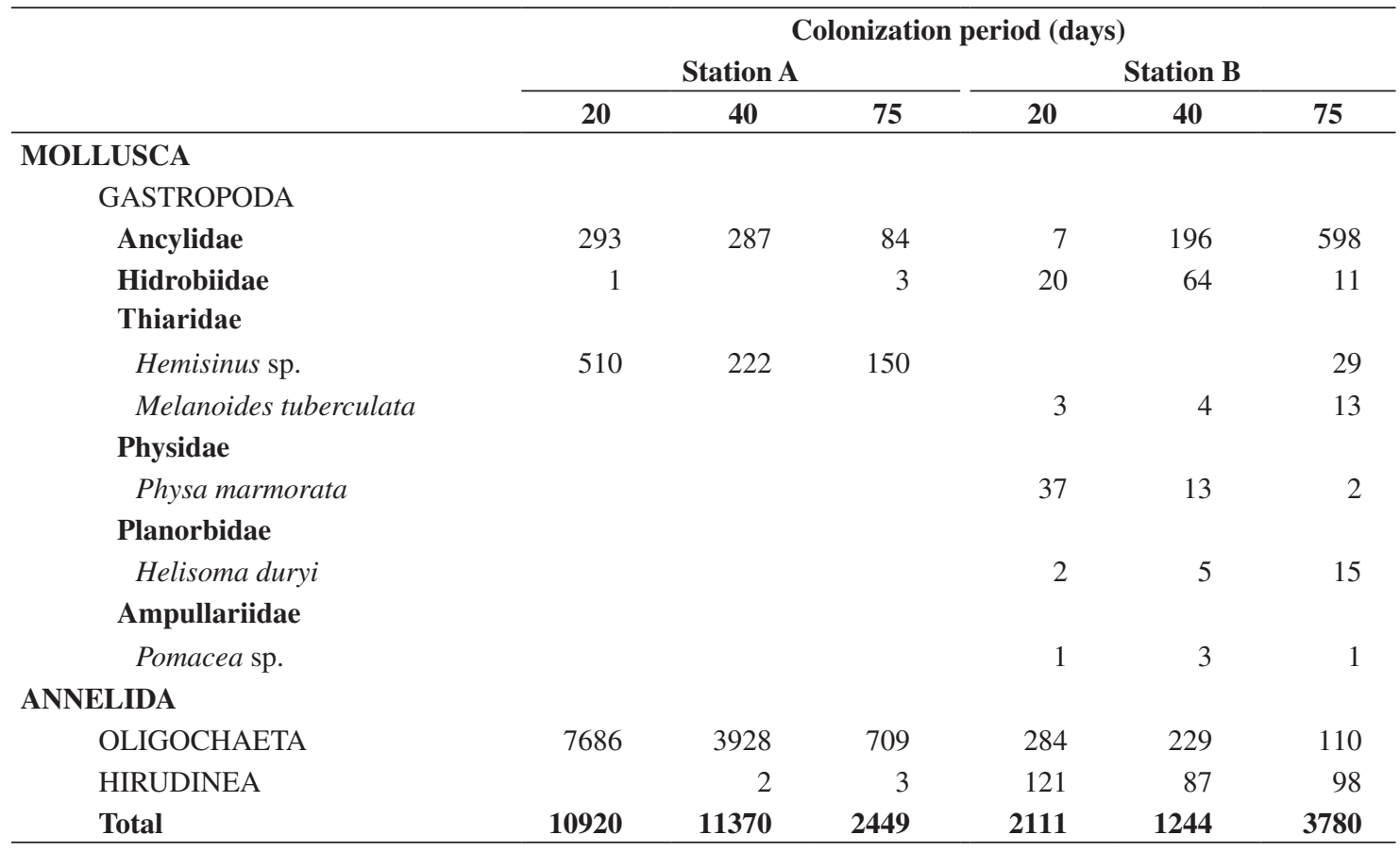

Table 2. Richness (S), Shannon index (H') and evenness (J) of the benthic macroinvertebates colonizing Typha domingensis leaves during different periods in stations A and B of the Imboassica Lagoon, Macaé, RJ, November 2000 through January 2001.

\begin{tabular}{ccccccccc}
\hline & \multicolumn{4}{c}{ Colonization periods (days) } \\
& \multicolumn{3}{c}{ Station A } & & \multicolumn{3}{c}{ Station B } \\
\cline { 2 - 4 } \cline { 7 - 9 } & $\mathbf{2 0}$ & $\mathbf{4 0}$ & $\mathbf{7 5}$ & & $\mathbf{2 0}$ & $\mathbf{4 0}$ & $\mathbf{7 5}$ \\
\hline S & 10 & 12 & 12 & & 28 & 26 & 27 \\
H' & 0.84 & 0.88 & 1.06 & & 2.21 & 2.31 & 1.93 \\
J & 0.36 & 0.35 & 0.43 & & 0.67 & 0.71 & 0.58 \\
\hline
\end{tabular}

tion in water quality (Figure 3). The samples of station A were positively correlated to Axis I, whereas samples of station B were negatively correlated (Figure 3). The structure of the fauna varied more between stations than among periods of colonization. In station A, the abundance of Oligochaeta was about 20 times higher than in station $\mathrm{B}$, contributing with $21 \%$ to the formation of Axis I. An exclusive taxon for station B, Campsurus melanocephalus Pereira and Da-Silva, 1991 (Ephemeroptera; Polymitarcyidae), showed a negative correlation with Axis I and contributed with $31 \%$ to its formation. Other organisms negatively correlated to Axis I were Coenagrionidae (3\%), Cladocera (6\%), Copepoda (5\%), Hirudinea (7\%), Ostracoda (4\%) and Cyrnellus (5\%) (Trichoptera: Polycentropodidae).

Axis II (20\% of the variation) might be interpreted as the quality of the substrate available for colonization. Chironomidae (50\%) and Oligochaeta (31\%) presented the highest contribution for this axis, both representing some of the most abundant macroinvertebrate organisms found in the two sampling stations. They also presented the highest variation among different colonization periods. Chironomidae was more abundant in the sample set removed after 75 days of colonization at station B, in comparison to the shorter periods (20 and 40 days). Otherwise, the highest abundance at station A was found in the sample set removed after 40 days and the lowest abundance at the 75 day sample set. Oligochaeta also presented decreased abundance in the 75 day sample set at both studied stations. Other organisms showing decreasing abundance in the longest colonization period (75 days) were Hirudinea, Hydrobiidae (Gastropoda), Copepoda and Cyrnellus, contributing with 3, 2, 3 and $4 \%$, respectively, to Axis II. Such results were more significant for station $\mathrm{A}$, where the individual abundance for several taxa showed a higher decrease over time. The observed reduction in abundance throughout the colonization period in station A may be a result of the advanced degradation of the leaves (they seemed softer and thinner when observed visually and when touched) in that station, as compared to those at station B.

\section{Discussion}

The rapid establishment of the macroinvertebrates community in station A demonstrates the role of sewage as an energy source for some groups. Oligochaeta and Chironomidae were the main organisms found in this samping station. Chironomidae is one of the most abundant groups of the benthic fauna in freshwater en- 
vironments (Coffman and Ferrington, 1996) and may be found in several different habitats (Pinder, 1986). The occurrence of Chironomidae as a dominant group has been observed in many studies on macroinvertebrate communities of natural and degraded environments (e.g., Nessimian and De Lima, 1997; Correia, 1999; Gonçalves-Jr, 1999; Araújo, 2000; Silveira, 2001). Chironomus and Goeldichironomus, the dominant genera of Chironomidae in station A, are considered as organisms with a high tolerance to habitats presenting high contents of organic matter and low oxygen levels (Ruse and Wilson, 1995). The abundance of these genera can be related to their collector-gatherer and, possibly, scraper feeding habits, as both kinds of organisms use debris as the main food item (Henriques-Oliveira et al., 2003). The increased abundance of Oligochaeta is correlated with environments subjected to a high input of domestic sewage, as pointed out by Navas-Pereira and Henrique (1996). Thus, organisms with a positive feedback response to sewage input, such as Oligochaeta, Chironomus and Goeldichironomus represent most of the disparity in the abundance of benthic organisms between the stations.

Despite the highest abundance of organisms in station $\mathrm{A}$, the greatest richness was found in station $\mathrm{B}$. The absence of some taxa in station A could be related to their low tolerance to organic pollution. According to Grosse et al. (1986), some Amphipoda families can be sensitive to high amounts of suspended organic material. Ephemeroptera and Trichoptera are often related to high or intermediate environmental integrity, as they are used as bioindicators in biological monitoring studies in freshwater environments. These taxa are, for example, very dependent on oxygen availability (Rosenberg and Resh, 1993; Lemly, 1982; Barbour et al., 1996; Silveira, 2001). The presence of Trichoptera and Ephemeroptera exclusively in station B indicates that these taxa present a high enough sensibility to react to the different amount of degradation found in the sampled stations.

Enrich-Prast and Fernandes (1998) found smaller rates of biological fixation of nitrogen by the periphyton associated to $T$. domingensis in station A of the Imboassica Lagoon. Such results were related to the formation of toxic compounds and to the inhibition of nitrogen fixation due to the presence of high nitrite and ammonia concentrations in polluted environments. The increase in the concentration of nitrogen and proteins from activities of bacteria, fungi, and epiphytic algae, may increase the attractiveness of the periphyton to macroinvertebrates (Suren and Lake, 1989). Thus, low values of nitrogen fixation could reduce the attractiveness of the periphyton, decreasing the diversity of invertebrates that feed upon these organisms. Fernandes (1998) observed smaller taxonomic richness of the periphytic community associated to leaves of $T$. domingensis in station A. The periphytic cover is considered an important factor influencing the structure of the macroinvertebrate community (Van Den Berg et al., 1997; Albertoni et al., 2001;
Nessimian and De Lima, 1997; Correia, 1999). Caenis cuniana Froehlich, 1969 (Ephemeroptera: Caenidae) feeds mainly on algae, vegetable fibers, and organic debris (Francischetti et al., 2001). Amphipoda species associated to the aquatic vegetation can feed on epiphytic algae, small animals and organic debris (Pennak, 1978; Grosse et al., 1986). Most Gastropoda are herbivores, including vegetable tissue (live or dead) and periphytic algae in their diet (Pennak, 1978), as exemplified by Physidae and Hidrobiidae (Suren and Lake, 1989; Cardoso et al., 1993). The pollution influence on the distribution of the benthic macroinvertebrate species can be attributed to change in food availability or to toxins associated to food (Thorne and Willians, 1997). The greatest herbivore richness found at station B can corroborate the results pointed out by Enrich-Prast and Fernandes (1998) and Fernandes (1998) on periphyton richness in stations $\mathrm{A}$ and $\mathrm{B}$.

The higher availability of organic matter close to the sewage discharge points may lead to the increase of abundance and biomass in the macroinvertebrates, as also observed in the same lagoon by Gonçalves Jr et al. (1998) and Albertoni et al. (2001). However, in the present study, the observed diversity values were smaller, in response to the richness decrease and the largest dominance of the more tolerant groups in station A. In studies of environmental biological integrity, higher values of evenness and richness may represent better environmental integrity. The increase in abundance and biomass of a few taxa may represent a negative effect of pollution, as only the more tolerant organisms are able to use the input of organic material as an energy subsidy.

Acknowledgments - We would like to thank Daniel Sheanan Colmenero Lin and Sandor Buys for helping in proofreading this manuscript. This work was supported by CNPq and FIOCRUZ.

\section{References}

ALBERTONI, EF., PALM-SILVA, C. and ESTEVES, FA., 2001. Macroinvertebrates associated with Chara in a tropical coastal lagoon (Imboassica Lagoon, Rio de Janeiro, Brazil). Hydrobiologia, vol. 457, p. 215-224.

ARAUJO, PRP., 2000. Estudo dos macroinvertebrados bentônicos para avaliação da qualidade de água dos rios Paraíba do Sul e Guandu - Estado do Rio de Janeiro, com relevância para análise de deformidades morfológicas em larvas de Chironomidae (Insecta: Diptera). Tese de Doutorado, Inst. Oswaldo Cruz /FIOCRUZ, Rio de Janeiro, RJ, Brasil, 132 p.

BARBOUR, MT., GERRITSEN, J. GRIFFITH, GE., FRYDENBORG, R., MCCARRON, E., WHITE, JS. and BASTIAN, ML., 1996. A framework for biological criteria for Florida streams using benthic macroinvertebrates. J. N. Am. Benthol. Soc., vol. 15, no. 2, p. 185-211.

CARDOSO, MCZ., HERNÁNDEZ, AMR. and CAICEDO, G., 1993. Indicadores ambientales de calidad de água em la cuenca Del rio Cauca. AINSO, vol. 2, p. 17-28. 
COFFMAN, WP. and FERRINGTON, LC., 1996. Chironomidae, In MERRIT, KW. and CUMMINS, RW. (eds.), An Introduction of Aquatic Insects of North America, 3rd ed., Chapter 26, Dubuque - Iowa, USA, Kendall Hunt Publishing Co. p. 635-754.

CORREIA, LCS., 1999. Comparação entre as assembléias de macroinvertebrados associadas a substratos naturais e artificiais na represa do Monjolinho (São Carlos - Sp). Dissertação de Mestrado, PPG-ERN/UFSCar, São Carlos, SP, Brasil, $78 \mathrm{p}$.

ENRICH-PRAST, A. and FERNANDES, VO., 1998. Taxas de fixação biológicas do nitrogênio na comunidade perifítica em Typha domingensis Pers. na Lagoa Imboassica. In Esteves, F. A. (ed.), Ecologia das lagoas costeiras do Parque Nacional da Restinga de Jurubatiba e do Município de Macaé (RJ), 1a ed., capítulo 4.6, Núcleo de Pesquisa Ecológicas de Macaé (NUPEM) - UFRJ, Rio de Janeiro, RJ, Brasil, p. 237-245

ESTEVES, FA., ISHII, I. H. and CAMARGO, AFM., 1984. Pesquisas limnológicas em 14 lagoas do litoral do Estado do Rio de Janeiro. In LACERDA, LD., ARAÚJO, DSD., CERQUEIRA, R. and TURCO, B. (orgs.). Restingas: Origem, Estrutura e Processos. CEUF, Niterói, p. 441-452.

ESTEVES, FA., 1998a. Lagoas Costeiras: Origem, Funcionamento e Possibilidade de Manejo, In ESTEVES, FA. (ed.), Ecologia das lagoas costeiras do Parque Nacional da Restinga de Jurubatiba e do Município de Macaé (RJ), 1a ed., capítulo 2.2, Núcleo de Pesquisa Ecológicas de Macaé (NUPEM) - UFRJ, Rio de Janeiro, RJ, Brasil, p. 63-87.

ESTEVES, FA., 1998b. Lagoa Imboassica: impactos antrópicos, propostas mitigadoras e sua importância para a pesquisa ecológica. In ESTEVES, FA. (ed.), Ecologia das lagoas costeiras do Parque Nacional da Restinga de Jurubatiba e do Município de Macaé (RJ), 1a ed., capítulo 6.3, Núcleo de Pesquisa Ecológicas de Macaé (NUPEM) - UFRJ, Rio de Janeiro, RJ, Brasil, p. 401-429.

FERNANDES, VO., 1998. Variação Temporal e Espacial na Composição da Comunidade Perifítica na Lagoa Imboassica. In ESTEVES, FA. (ed.), Ecologia das lagoas costeiras do Parque Nacional da Restinga de Jurubatiba e do Município de Macaé (RJ), 1a ed., capítulo 4.5, Núcleo de Pesquisa Ecológicas de Macaé (NUPEM) - UFRJ, Rio de Janeiro, RJ, Brasil, p. 221-236.

FRANCISCHETTI, C., DA-SILVA, ER. and SALLES, FF., 2001. A alimentação de ninfas de Caenis cuniana FROEHLICH, 1969 (Ephemeroptera, Caenidae) em um brejo temporario da restinga de Maricá, Estado do Rio de Janeiro. Bol. Mus. Nac., N.S., Zool., vol. 446, p. 1-6.

FURTADO, A., 1994. Contribuição das macrófitas aquáticas Typha domingensis Pers. (TYPHACEAE) e Eleocharis cf. fistulosa (Poir.) Link (CYPERACEAE) para o estoque de nutrientes e energia da Lagoa Imboassica (Macaé, RJ). Dissertação de Mestrado em Ecologia, PPGE-UFRJ, Rio de Janeiro, RJ, Brasil, XII + 104p.

GONÇALVES-Jr, JF., 1999. Colonização por invertebrados em detrito de macrófitas aquáticas (Typha domingensis e Nimphaea ampla) na Lagoa Jurubatiba (Cabiúnas), Macaé, RJ. Dissertação de Mestrado em Ecologia, PPGE-UFRJ, Rio de Janeiro, RJ, Brasil, 56p.

GONÇALVES Jr., JF., FONSECA, JJI. and CALLISTO, MFP., 1998. Population dynamic of Heleobia australis (Gastropoda) in a coastal lagoon (Rio de Janeiro, Brazil). Verh. Internat. Verein. Limnol, vol. 26, p. 2056-2057.

GROSSE, DJ., PAULEY, GB. and MORAN, D., 1986. Species profiles: life histories and environmental requirements of coastal fishes and invertebrates (Pacific Northwest) - Amphipods. U.S. Fish Wildl. Serv. Biol. Rep. 82 (11.69). U.S. Army Corps of Engineers, TR El-82-4, 15 p.

HENRIQUES-DE-OLIVEIRA, C., 2002. Macroinvertebrados associados à Typha domingensis Pers (Typhaceae) em duas lagoas no litoral norte fluminense e sua utilização em programas de biomonitoramento. Dissertação de Mestrado em Ecologia, PPGE-UFRJ, Rio de Janeiro, RJ, Brasil, xv + 92 p.

HENRIQUES-OLIVEIRA, AL., NESSIMIAN, JL. and DORVILLÉ, LFM., 2003. Feeding habitats of chironomid larvae (Insecta, Diptera) from a stream in the Floresta da Tijuca, Rio de Janeiro, Brazil. Braz. J. Biol., vol. 63, no. 2, p. 269-281.

HYNES, HBN., 1970. The ecology of running waters. 1st edition. University of Toronto Press, Toronto, 555p.

KUHLMANN, ML., 2000. Invertebrados Bentônicos e Qualidade Ambiental. Tese de Doutorado, Instituto de Biociências da Universidade de São Paulo, Dpto. Ecologia/USP, São Paulo, SP, Brasil, 133p.

LEMLY, AD., 1982. Modification of benthic insect communities in polluted streams: combined effects of sedimentation and nutrient enrichment. Hydrobiologia, vol. 87, p. 229-245.

LUDWING, JA. and REYNOLDS, JF., 1988. Statistical Ecology: a primer on methods and computing. $1^{\text {st }}$ ed., USA, John Wiley \& Sons, Inc., 337p.

MAGURRAN, AE., 1988. Ecological Diversity and Its Measurement. $1^{\text {st }}$ edition, London, Chapman \& Hall, 179p.

MINSHALL, GW., 1984. Aquatic insect- substratum relationships, In RESH, VH. and ROSENBERG, DM. (eds.), The ecology of Aquatic Insects. $1^{\text {st }}$ ed., New York, USA, Praeger Publishers, p. 358-400.

NAVAS-PEREIRA, D. and HENRIQUE, RM., 1996. Aplicação de índices biológicos numéricos na avaliação da qualidade ambiental. Rev. Brasil Biol., vol. 56, no. 2, p. 441-450.

NESSIMIAN, JL. and DE LIMA, IHAG., 1997. Colonização de três espécies de macrófitas por macroinvertebrados aquáticos em um brejo no litoral do Estado do Rio de Janeiro. Acta Limnol. Brasil, vol. 9, p. 149-163.

ODUM, E., 1985. Trends Expected in stressed Ecosystems. BioScience, vol. 35, p. 7, p. 419-422.

ODUM, E., 1988. Ecologia. Rio de Janeiro, RJ, Brasil, Editora Guanabara Koogan S.A., 434p.

PANOSSO, RF., ATTAYDE, JL., MUEHE, D., 1998. Morfometria das lagoas Imboassica, Cabiúnas, Comprida e Carapebus: Implicações para seu funcionamento e manejo. In ESTEVES, FA. (ed.), Ecologia das lagoas costeiras do Parque Nacional da Restinga de Jurubatiba e do Município de Macaé $(R J)$, 1a ed., capítulo 3.1, Núcleo de Pesquisa Ecológicas de Macaé (NUPEM) - UFRJ, Rio de Janeiro, RJ, Brasil, p. $91-108$

PENNAK, RW., 1978. Fresh-Water Invertebrates of The United States, 2nd ed., New York, USA, John Wiley \& Sons, Inc., 803p. 
PETRUCIO, MM. and FURTADO, ALS., 1998. Concentração de nitrogênio e fósforo da coluna d'água da lagoa Imboassica, In ESTEVES, FA. (ed.), Ecologia das lagoas costeiras do Parque Nacional da Restinga de Jurubatiba e do Município de Macaé (RJ), 1a ed., capítulo 4.5, Núcleo de Pesquisa Ecológicas de Macaé (NUPEM) - UFRJ, Rio de Janeiro, RJ, Brasil, p. 1213-133.

PINDER, LCV., 1986. Biology of Freshwater Chironomidae. Ann. Rev. Entomol., vol. 31, p. 1-23.

RESH, VH. and ROSENBERG, DM., 1984. The Ecology of Aquatic Insect, $1^{\text {st }}$ ed., New York, USA, Praeger Publishers, $625 \mathrm{p}$.

ROHLF, FJ., 1992. NTSYS-pc Numerical taxonomy and Multivariate Analysis System. University of New York, New York, USA, Setauret, 244p.

ROSENBERG, DM., 1993. and RESH, VH. Freshwater Biomonitoring and Benthic Macroinvertebrates, $1^{\text {st }}$ ed., New York, USA, Chapman \& Hall, 483p.

RUSE, LP. and WILSON, RS., 1995. Long-term assessment of water and sediment quality of the River Thames using Chironomid pupal skins. In: CRANSTON, P. (ed.), Chironomids: From genes to ecosystems. CSIRO Australia, 482p.

SILVEIRA, MP., 2001. Estudos das comunidades de macroinvertebrados aquáticos e sua utilização na avaliação da qualidade da água na bacia do Rio Macaé, Estado do Rio de
Janeiro. Dissertação de Mestrado em Ecologia, PPGE-UFRJ, Rio de Janeiro, RJ, Brasil, 152p.

SOFFIATI, A., 1998. Aspectos Históricos das Lagoas do Norte do Estado do Rio de Janeiro, In ESTEVES, FA. (ed.), Ecologia das Lagoas Costeiras do Parque Nacional da Restinga de Jurubatiba e do Município de Macaé (RJ). 1a ed., capítulo 1, Núcleo de Pesquisa Ecológicas de Macaé (NUPEM) - UFRJ, Rio de Janeiro, RJ, Brasil, p. 3-35.

SUREN, AM. and LAKE, PL., 1989. Edibility of fresh and decomposing macrophytes to three species of freshwater invertebrates herbivores. Hydrobiologia, vol. 178, p. 165-178.

THORNE, RJ. and WILLIANS, PW., 1997. The response of benthic macroinvertebrates to pollution in developing countries; a multimetric system of bioassessment. Freshwater Biology, vol. 37, p. 671-686.

VAN DEN BERG, MS., COOPS, H., NOORDHUIS, R., SCHIE, J. and SIMONS, J., 1997. Macroinvertebrates communities in relation to submerged vegetation in two Chara dominated lakes. Hydrobiologia, vol. 342/343, p. 143-150.

WALKER, I., 1998. Population dynamics of Chironomidae (Diptera) in the central amazonian blackwater river TurumãMirim (Amazonas, Bazil). In NESSIMIAN, JL. and CARVALHO, AL. (eds.), Ecologia de Insetos Aquáticos Oecologia Brasiliensis, vol. 5, p. 235-252.

WARD, JV., 1992. Aquatic insects ecology 1. Biology and habitat. $1^{\text {st }}$ ed., Singapore, John Wiley \& Sons, Inc., 438p. 